\title{
Experimental investigations on thermal performance of solar air heater with different absorber plates
}

\author{
Umayorupagam P. Arunachalam, Mohan Edwin* \\ Department of Mechanical Engineering, University College of Engineering, Nagercoil, Anna \\ University Constituent College, Konam, Nagercoil, 629004, India \\ Email: edwinme1980@gmail.com
}

\begin{abstract}
The use of special kind of arrangement absorber plate is an effective and economic method to improve the thermal performance of a solar air heater. In this paper, the thermal performance of a solar air heater was experimentally investigated with different absorber plates with a mass flow rate of $20 \mathrm{~kg} / \mathrm{h}$ and $25 \mathrm{~kg} / \mathrm{h}$ with different arrangements of absorber plates such as glass plates and galvanized iron (GI) sheet varying mass flow rates of air. It was observed that thermal efficiency was increased by $9.4 \%$ while using the glass plate absorber compared to the galvanized iron (GI) sheet absorber plate.
\end{abstract}

Keywords: Solar Air Heater, Glass Plate, Galvanized Iron (GI) Sheet, Thermal Efficiency, Heat Transfer.

\section{INTRODUCTION}

Solar air heaters $(\mathrm{SAH})$ are prevalent in several solar energy applications, especially space heating, drying and paint spraying operations, because of their inherent simplicity, cheapness and most widely used collection devices. The main drawback of a SAH is that the heat-transfer coefficient between the absorber plate and the air stream was low, which results in a lower thermal efficiency of the heater [1]. However, different modifications and techniques were adopted to increase the performance of solar air heaters, such as fins, artificial roughness inclined V-shaped, chamfered and combinations of different geometries have been investigated $[2,3,4]$. From the literature, it has been observed that all the elements of a solar air heater such as; an absorber tray, flow channel ducts, glazing, insulation, extended surfaces, as well as the tilt angle, have a significant effect on the thermal performance of the system $[5,6]$.

The researchers have carried out works towards the improvement on the performance of the solar air heaters. Thermal efficiency of solar air heater greatly depends on time, solar insolation and mass flow rate [7, 8]. The highest collector efficiency and air temperature rise were achieved by the finned collector, whereas the lowest values were obtained from the collector without using fins[9]. The values show that the thermal efficiency of the SAH increases with the increase in the air flow rate [10].The glass plate absorbers are introduced to enhance the thermal efficiency of the air heaters. Glass plates are arranged in two layers for increasing heat transfer area, leading to improved thermal performance [11]. The efficiencies of single glazed, double glazed and packed bed solar air heaters for the flow rate of $0.02 \mathrm{~m} / \mathrm{s}-\mathrm{m}^{2}$ were
$30.29 \%, 45.05 \%$ and $71.68 \%$ respectively [12]. The flow rate of air and plate configurations have a great effect on net energy gained from the air heater [13]. The results show that as the temperature of the air entering the collector increases above the ambient temperature, the heat losses from the collector become larger and the useful energy collected becomes less [14].

In consonance with this, the central focus of this work is to investigate experimentally the effect of the thermal performance of the solar air heater with different types of absorber plates such as glass plate and galvanized iron (GI) plate with varying the air mass flow rate. This paper presents an efficiency evaluation of different absorber plates under same operating conditions and at different velocity conditions. An experimental set up of the solar air heater and the thermal performance analysis of SAH with different operating modes are described in the following sections.

\section{DESCRIPTION OF THE EXPERIMENTAL SET-UP}

The construction of solar air heaters was made by means of galvanized iron (GI) sheet as absorber plate and by a glass plate as absorber plate. These two set up were fabricated and installed. Air is the heat transfer medium in both the air heaters. Air passed through the inlet straighter by means of air blower. The air gains temperature as it passes over the absorber plates. This may lead to increase in the temperature of the working fluid of the system. The observations were recorded and a comparison study was made for both copper plate collector and glass plate collectors. Figure 1 shows the schematic diagram of a solar air heating (SAH) system. 
It consists of horizontal shaft mounted with a blower on the shaft which is directly coupled to the motor. When the motor is switched $\mathrm{ON}$, a small pressure difference was developed inside the casing of the blower which causes the air flow from the atmosphere through glass plate collector and copper plate collector and then to the outlet section.

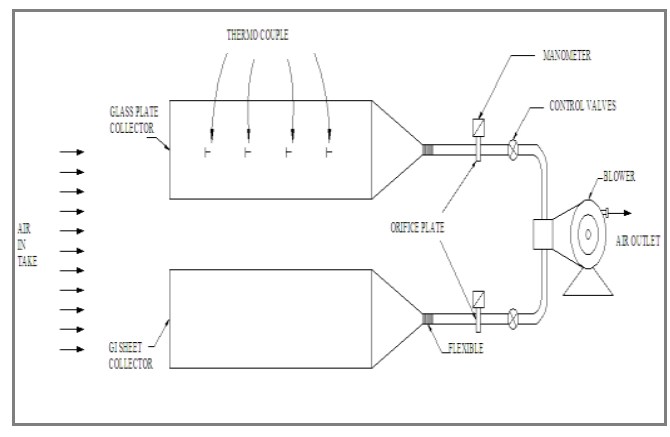

Figure 1. Schematic diagram of SAH system

Copper constant thermocouples are used to measure the top glass plate temperatures, absorber plate (copper plate collector and glass plate collector) temperatures. The Autotransformer is used to vary the speed of the blower. Anemometer is used to evaluate the air velocity through the system and intensity of the solar radiation is measured by pyranometer. Design details of solar air heater is shown in Table 1.

Table 1. Design details of solar air heater

\begin{tabular}{|c|c|}
\hline Components & Details \\
\hline Internal area of collector $\left(\mathrm{m}^{2}\right)$ & $1776 \times 786 \times 184$ \\
\hline Absorber plate material & Glass, galvanized iron (GI) \\
\hline Working fluid & Air \\
\hline Collector tilt angle & $22^{\circ}$ Latitude \\
\hline Thickness of absorber plate & $8 \mathrm{~mm}$ \\
\hline Diameter of inlet hole & $90 \mathrm{~mm}$ \\
\hline Diameter of outlet hole & $65 \mathrm{~mm}$ \\
\hline
\end{tabular}

\subsection{Assumptions}

In the following the assumptions considered in the analysis are:

-The system operates under steady state conditions;

-Air, absorber and bottom plate temperatures change only in the direction of the air flow;

-Air temperature is assumed uniform through the cross section;

-Heat conduction is considered negligible;

- Outside convective heat transfer coefficient is constant along the length of solar air heater [15].

\section{TYPES OF EXPERIMENTATION}

The experiments were performed for both types of air heaters in actual solar conditions by changing the absorber plates (same operating conditions, different velocity conditions and various glass plate arrangements).

The efficiency of solar air heater with different absorber plates made of glass plate and galvanized iron (GI) sheet is determined from the experimental observations. The thermal performance evaluation and the comparison of its thermal efficiency against the efficiencies of other collectors with different absorber plates were carried out. The total solar radiation incident on the surface of the collector was measured by the use of Pyranometer which was located adjacent to the glazing cover, at the same plane, facing due south. The observations (ambient temperature, absorber plate temperatures at several selected locations and air flow rates.) were recorded at time intervals of 30 minutes. The air was provided by a radial fan with a maximum $0.5 \mathrm{~kW}$ power. The radial fan placed at the outlet of the collectors sucked in the air. The pressure loss was measured by means of a manometer placed between inlet and outlet of the collector. All tests began at 9 AM and ended at 5 PM. Figure 2 shows that the photographical view of the experimental set up of the solar air heater set up.

\subsection{Uncertainity analysis}

Root Sum Square method can be used to determine the combined effect of random measurement errors. According Root Sum Square method to the result $\mathrm{R}$ is a given function of independent variables $\mathrm{x}_{1}, \mathrm{x}_{2}$, Thus

$$
R=R\left(X_{1}, X_{2}, X_{3}, \ldots . X_{n}\right)
$$

Let $\mathrm{w}_{\mathrm{R}}$ be the uncertainty in the result and $\mathrm{w}_{1}, \mathrm{w}_{2}, \mathrm{w}_{3} \ldots \mathrm{w}_{\mathrm{n}}$ be the uncertainties in the independent variables. If the uncertainties in the independent variables are all given with the same odds, then the uncertainty in the result having these odds is given by

$w_{R}=\sqrt{\left(\frac{\partial R}{\partial x_{1}} \times w_{1}\right)^{2}+\left(\frac{\partial R}{\partial x_{2}} \times w_{2}\right)^{2}+\left(\frac{\partial R}{\partial x_{3}} \times w_{3}\right)^{2}+\cdots+\left(\frac{\partial R}{\partial x_{n}} \times w_{n}\right)^{2}}$

Temperature of different elements of solar still are measured using a RTD sensor with an error of $+/-1^{\circ} \mathrm{C}$.

The detailed error and experimental uncertainty are discussed in Table 2.

Table 2. Error details and experimental uncertainty of SAH

\begin{tabular}{|c|c|c|c|}
\hline Instrument & $\begin{array}{c}\text { Standard } \\
\text { Uncertainity }\end{array}$ & Range & $\begin{array}{c}\text { Error } \\
(\boldsymbol{\%})\end{array}$ \\
\hline Thermocouple & $\pm 0.5^{\circ} \mathrm{C}$ & $0-100^{\circ} \mathrm{C}$ & 0.25 \\
\hline Pyranometer & $\pm 1 \mathrm{~W} / \mathrm{m}^{2}$ & $0-2000 \mathrm{~W} / \mathrm{m}^{2}$ & 5 \\
\hline Anemometer & $\pm 0.8 \mathrm{~m} / \mathrm{s}$ & $0.15-30 \mathrm{~m} / \mathrm{s}$ & 5 \\
\hline $\begin{array}{c}\text { Collector area } \\
\text { (Tape measure) }\end{array}$ & $\pm 0.005 \mathrm{~m}$ & $0-10 \mathrm{~m}$ & 0.01 \\
\hline
\end{tabular}

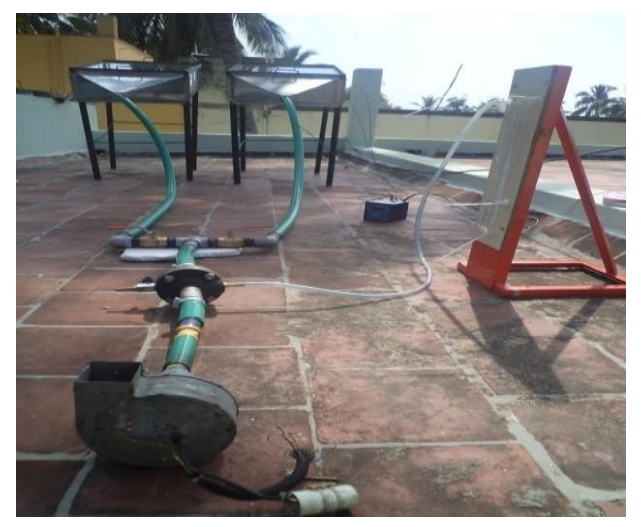

Figure 2. Photographic view of experimental setup 


\section{THERMAL PERFORMANCE ANALYSIS}

The theoretical model employed for the study of the solar collector using a thermal energy balance is derived in equation (1) and (2)

[Accumulated energy $]+[$ Energy gain $]=[$ Absorbed energy $]-$ [Energy Loss]

$\mathrm{M}_{\mathrm{p}} \mathrm{c}_{\mathrm{pp}}\left(\mathrm{dT} \mathrm{T}_{\mathrm{p}, \text { ave }} / \mathrm{dt}\right)+\dot{\mathrm{m}} \mathrm{c}_{\mathrm{p}}\left(\mathrm{T}_{\mathrm{a}, \text { out }}-\mathrm{T}_{\mathrm{a}, \text { in }}\right)=\eta \mathrm{IA}_{\mathrm{c}}-\mathrm{U}_{\mathrm{c}}\left(\mathrm{T}_{\mathrm{p}, \text { ave }}-\right.$ $\left.\mathrm{T}_{\mathrm{amb}}\right) \mathrm{A}_{\mathrm{c}}$

The optical yield ( $\eta$ ) and the energy loss coefficient (UC) are the parameters that characterize the behaviour of the solar collector. The term ho represents the fraction of the solar radiation absorbed by the plate and depends mainly on transmittance of the transparent covers and on the absorbance of the plate.

The thermal efficiency of the solar collectors $\left(\eta_{c}\right)$ is defined as the ratio between the energy gain and the solar radiation incident on the collector plane and it is expressed in eqn (3),

$\eta_{\mathrm{c}}=\dot{\mathrm{m}} \mathrm{C}_{\mathrm{P}}\left(\mathrm{T}_{\mathrm{a}, \text { out }}-\mathrm{T}_{\mathrm{a}, \text { in }}\right) /\left(\mathrm{IA}_{\mathrm{C}}\right)$

\section{RESULTS AND DISCUSSION}

The performance tests of SAHs were conducted on days with clear sky conditions. The collectors were instrumented with T-type thermocouples for measuring temperatures of flowing air at inlet and outlet of the collector, and the ambient temperature. It is worth noting that the flow rate is basically decided from the rise of the temperature of the air desired for a particular application.

The collector efficiency improvements for both types of SAHs were calculated using Eq. (3). The performances of the absorber plates (Glass and galvanized iron (GI) plates) were investigated for the mass flow rate of $20 \mathrm{~kg} / \mathrm{h}$ and $25 \mathrm{~kg} / \mathrm{h}$ for with black coated (Type-I) and without black coated (Type-II) by the experiments which had been performed during one month period.

Figure 3 shows the results of experiments regarding the efficiency variations of black coated SAH (Type- I) using different absorber plate with time for the $20 \mathrm{~kg} / \mathrm{h}$ as the mass flow rate. It was observed that the efficiencies increase to a maximum value at 12:30-02:00 PM in the afternoon, and then they start to decrease as the time proceeds further. The efficiency variation of the same collector (Type I) with the flow rate of $25 \mathrm{~kg} / \mathrm{h}$ is indicated by the Figure 4 and it was noticed that the efficiency increase to a maximum value around 12:30-02:30 PM in the afternoon, and then starts to decrease in the evening.

Figure 5 and 6 show the efficiency variations of the SAHs (Type II) with the mass flow rates of $20 \mathrm{~kg} / \mathrm{h}$ and $25 \mathrm{~kg} / \mathrm{h}$ in respect of time, during the experiments. It was observed that the efficiency increases gradually and reaches the maximum value around 12:30-02:30 PM for both mass flow rates and almost same kind of variation was noticed. The efficiency of the Type I (black coated) is higher than that of Type II (without black coated). The air flow rate of air through the duct influences the collector efficiency. The results show that the collector efficiency increases with increasing the air mass flow rate of air and solar radiation. The black coating also plays a vital role in the improvement of efficiency.

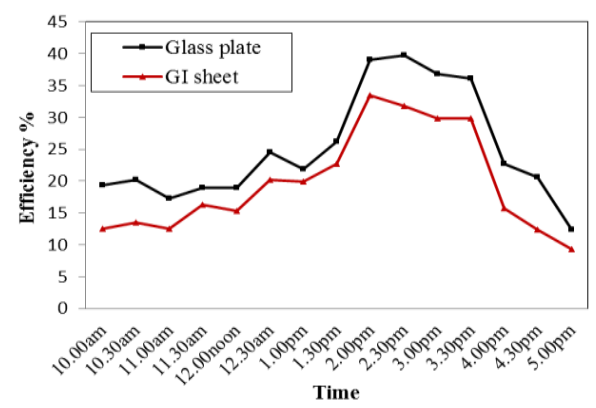

Figure 3. Variation of efficiency of the $\mathrm{SAH}(\dot{\mathrm{m}}=20 \mathrm{~kg} / \mathrm{h}$, Type I) on different absorber plate with time

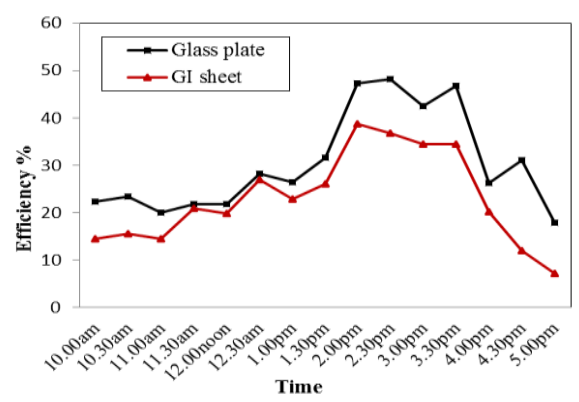

Figure 4. Variation of efficiency of the $\mathrm{SAH}(\dot{\mathrm{m}}=25 \mathrm{~kg} / \mathrm{h}$, Type I) on different absorber plate with time

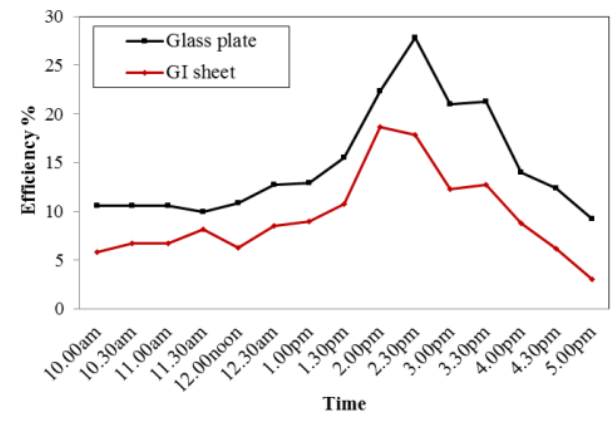

Figure 5. Variation of efficiency of the SAH $(\dot{\mathrm{m}}=20 \mathrm{~kg} / \mathrm{h}$, Type II) on different absorber plate with time

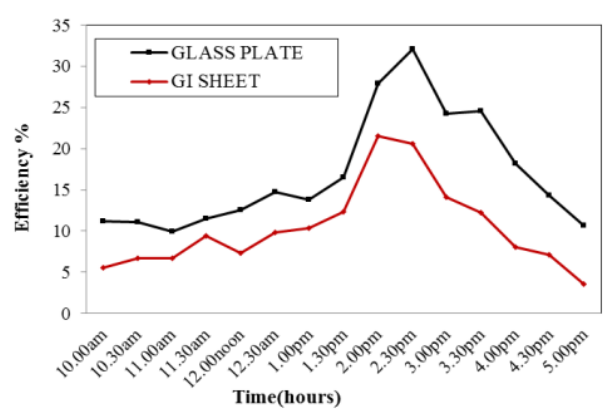

Figure 6. Variation of efficiency of the $\mathrm{SAH}(\dot{\mathrm{m}}=25 \mathrm{~kg} / \mathrm{h}$, Type II) on different absorber plate with time

It was observed that increasing the air velocity through the absorber tubes with the increase of air mass flow rate, and thermal efficiency increases significantly. The cause of this noticeable increase in thermal efficiency is attributable to changing conditions flow from laminar to turbulent regime and consequently to the heat transfer enhancement. 


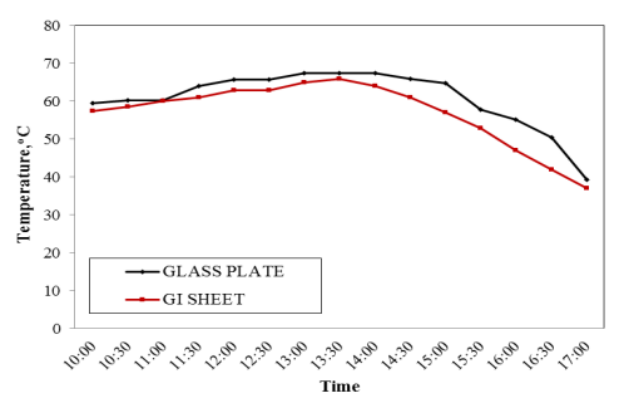

Figure 7. Variation of temperature of the $\mathrm{SAH}(\dot{\mathrm{m}}=20 \mathrm{~kg} / \mathrm{h}$, Type I) on different absorber plate with time

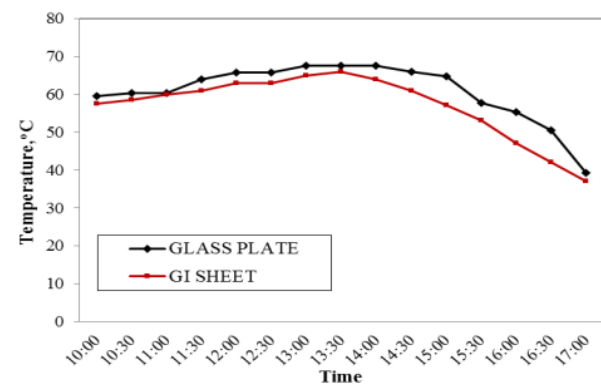

Figure 8. Variation of temperature of the $\mathrm{SAH}(\dot{\mathrm{m}}=25 \mathrm{~kg} / \mathrm{h}$, Type I) on different absorber plate with time

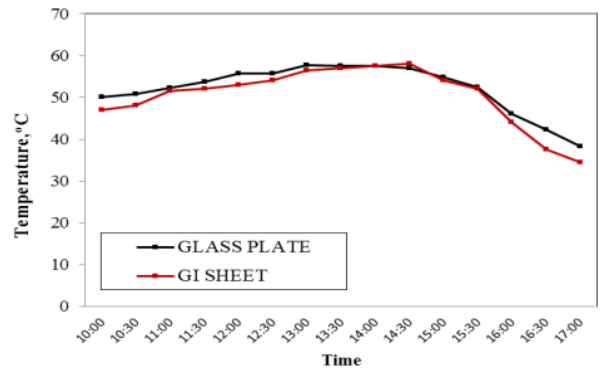

Figure 9. Variation of temperature of the $\mathrm{SAH}(\dot{\mathrm{m}}=20 \mathrm{~kg} / \mathrm{h}$, Type II) on different absorber plate with time

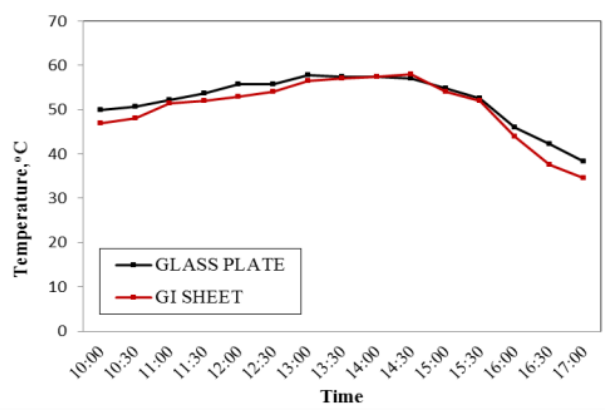

Figure 10. Variation of temperature of the $\mathrm{SAH}(\dot{\mathrm{m}}=25 \mathrm{~kg} / \mathrm{h}$, Type II) on different absorber plate with time

Figure 7 and 8 indicate the mean temperature of absorber plate (Type -I) with time for the mass flow air of $20 \mathrm{~kg} / \mathrm{h}$ and $20 \mathrm{~kg} / \mathrm{h}$ respectively. The highest intensity of solar radiation obtained is around $989 \mathrm{~W} / \mathrm{m}^{2}$ at noon and then starts to decrease as the time proceeds further. The average increase in air temperature was found to be $13.7^{\circ} \mathrm{C}$ for a mass flow rate of $20 \mathrm{~kg} / \mathrm{h}$ while $12.5^{\circ} \mathrm{C}$ was noticed if the mass flow is increased by $5 \mathrm{~kg} / \mathrm{h}$. The similar kind of phenomena was noticed in SAH of Type - II and the mean temperatures of the absorber plates at similar conditions are indicated by Figure 9 and 10. The higher exit air temperature was observed in black coated Glass plate with less mass flow rate of air than galvanized iron (GI) sheet plate.

\section{CONCLUSIONS}

This work demonstrates the investigation of Solar Air Heater performances using Glass and galvanized iron (GI) plate as absorber plate with and without black coated surfaces under different operating conditions. The efficiency of the $\mathrm{SAH}$ increases with increase in mass flow rate (from $20 \mathrm{~kg} / \mathrm{h}$ to $25 \mathrm{~kg} / \mathrm{h}$ ) while the temperature gain by system reduces. It is observed that the maximum temperature difference of $58.933^{\circ} \mathrm{C}$ and $63.68^{\circ} \mathrm{C}$ was achieved by the galvanized iron (GI) sheet and glass plate air heater respectively. The thermal efficiency of $29.62 \%$ and $34.74 \%$ were able to obtain when the system was fed with an air flow of $25 \mathrm{~kg} / \mathrm{h}$ using galvanized iron (GI) sheet and glass plate as absorber plates. It was noticed that these was $9.4 \%$ increase in the collector efficiency in the glass plate than galvanized iron (GI) sheet absorber plate collector. The investigations by this work may be one of the useful findings to improve the performance of the collectors of the Solar Air Heaters which is essential for effective utilization of solar energy.

\section{REFERENCES}

[1] Mittal M.K., Varun G., Saini R.P., Singal S.K. (2007). Effective efficiency of solar air heaters having different types of roughness elements on the absorber plate, Energy, Vol. 32, No. 5, pp. 739-745. DOI: 10.1016/j.energy.2006.05.009

[2] Siddhartha V. (2010). Thermal performance optimization of a flat plate solar air heater using genetic algorithm, Applied Energy, Vol. 87, No. 5, pp. 1793-1799. DOI: $10.1016 /$ j.apenergy.2009.10.015

[3] Zhuang C.L., Fu B.H., Huang G.Q., Zhang H.Y. (2016). Optimization of the structure of a solar air heater fitted with V-shaped perforated baffles, International Journal of Heat and Technology, Vol. 34, No. 4, pp. 604-610. DOI: 10.18280/ijht.340408

[4] Bhattacharyya S., Chattopadhyay H., Bandyopadhyay S., Roy S., Pal S., Bhattacharjee S. (2016). Experimental investigation on heat transfer enhancement by swirl generators in a solar air heater duct, International Journal of Heat and Technology, Vol. 34, No. 2, pp. 191-196. DOI: 10.18280/ijht.340206

[5] Saxena A.V., El-Sebaii A.A. (2015). A thermodynamic review of solar air heaters, Renewable and Sustainable Energy Reviews, Vol. 43, pp. 863890. DOI: $10.1016 /$ j.rser.2014.11.059

[6] Labed A., Moummi N., Benchabane A., Zellouf M. (2015). Experimental analysis of heat transfer in the flow channel duct of solar air heaters, International Journal of Heat and Technology, Vol. 33, No. 3, pp. 97 -102. DOI: 10.18280/ijht.330314

[7] Patel V.B., Chaudhary S.N. (2013). Thermal analysis on solar air heater with corrugated absorber plate and amul cool aluminum cans, Indian Journal of Applied 
Research, Vol. 3, No. 6, pp. 209-212. DOI: 10.15373/2249555X

[8] Al-Kamil M.T., Al-Ghareeb A.A. (1997). Effect of thermal radiation inside solar air heaters, Energy Conversion and Management, Vol. 38, No. 14, pp.

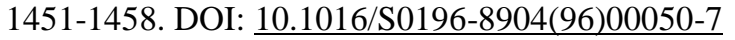

[9] Chabane F., Moummi N., Benramache S. (2014). Experimental study of heat transfer and thermal performance with longitudinal fins of solar air heater, Journal of Advanced Research, Vol. 5, pp. 183-192. DOI: $10.1016 /$ j.jare.2013.03.001

[10] Labed A., Moummi N., Benchabane A., Zellouf M. (2015). Experimental analysis of heat transfer in the flow channel duct of solar air heaters (SAHs), International Journal of Heat and Technology, Vol. 33, No. 3, pp. 97-102. DOI: 10.18280/ijht.330314

[11] Tchinda R. (2009). A review of the mathematical models for predicting solar air heaters systems, Renewable and Sustainable Energy Reviews, Vol. 13, No. 8, pp. 1734-1759. DOI: 10.1016/j.rser.2009.01.008

[12] Gill R.S., Sukhmeet S., Singh P.P. (2012). Low cost solar air heater, Energy Conversion and Management, Vol. 57, pp. 131-142. DOI: 10.1016/j.enconman.2011.12.019

[13] Khattab N.M. (2001). Evaluation of perforated plate solar air heater, International Journal of Solar Energy, Vol. 21, No. 1, pp. 45-62. DOI: 10.1080/01425910008914363

[14] Singh S.N. (2013). Flow and heat transfer studies in a double-pass counter flow solar air heater, International Journal of Heat and Technology, Vol. 31, No. 2, pp. 37-42. DOI: $\underline{10.18280 / i j h t .310205}$

[15] Aissaoui F., Benmachiche A.H., Brima A., Derradji B., Belloufi Y. (2016). Experimental and theoretical analysis on thermal performance of the flat plate solar air collector, International Journal of Heat and Technology, Vol. 34, No. 2, pp. 213-220. DOI: $\underline{10.18280 / \text { ijht.340209 }}$

\section{NOMENCLATURE}

$\mathrm{A}_{\mathrm{c}} \quad$ collector surface area, $\mathrm{m}^{2}$

B collector tilt angle, $\mathrm{W} / \mathrm{m}^{2}$

C collector perimeter, $\mathrm{m}$

$\mathrm{c}_{\mathrm{p}} \quad$ specific heat of air, $\mathrm{J} / \mathrm{kgK}$

GT solar radiation intensity, $\mathrm{W} / \mathrm{m}^{2}$

$\mathrm{K}$ thermal conductivity of insulation material, $\mathrm{W} / \mathrm{mK}$

$\mathrm{L}$ thickness of the insulation material, $\mathrm{m}$

m mass flow rate, $\mathrm{kg} / \mathrm{s}$

$\mathrm{N}$ number of glass cover

$\mathrm{Q}_{\mathrm{c}} \quad$ reflectance rate of transparent cover, \%

SAH solar air heater

GI galvanized iron

$\mathrm{T}$ temperature, $\mathrm{K}$

$\mathrm{V}$ fluid velocity, $\mathrm{m} / \mathrm{s}$

$\eta \quad$ Thermal efficiency

$\rho$ density of air, $\mathrm{kg} / \mathrm{m}^{3}$

$\mathrm{U}_{\mathrm{c}} \quad$ overall convective heat transfer coefficient, $\mathrm{W} / \mathrm{m}^{2}$

$\mathrm{T}_{\mathrm{amb}}$ ambiant temperature, $\mathrm{K}$

\section{Subscripts}

$\begin{array}{ll}\text { amb } & \text { ambiant } \\ \text { in } & \text { inlet } \\ \text { out } & \text { outlet } \\ \mathrm{c} & \text { collector } \\ \text { ave } & \text { average } \\ \mathrm{p} & \text { plate surface }\end{array}$

